\title{
INTRAPHAGOCYTIC PROTECTION OF STAPHYLOCOCCI FROM EXTRACELLULAR PENICILLIN
}

\author{
C. LAM* AND G. E. MATHISON $\dagger$ \\ Department of Microbiology, Queen Elizabeth College, Campden Hill Road, London \\ W8 7 AH
}

\begin{abstract}
SUmmaRY. In a system in which unphagocytosed bacteria were removed by differential centrifugation after a 30 -min phagocytosis period, staphylococci associated with rabbit polymorphonuclear (PMN) leukocytes were completely protected from the effects of benzyl penicillin $1 \mu \mathrm{g} / \mathrm{ml}$, but not completely protected from the effects of 5 $\mu \mathrm{g} / \mathrm{ml}$. When unphagocytosed bacteria were lysed with lysostaphin, effective protection could be observed over a range of penicillin concentrations from 0.25 to $200 \mu \mathrm{g} / \mathrm{ml}$. ${ }^{14} \mathrm{C}$-benzyl penicillin failed to accumulate in rabbit PMN leukocytes, whether or not they had previously phagocytosed staphylococci, in conditions in which mouse peritoneal macrophages readily accumulated penicillin. Mixed granule extracts prepared from the PMN leukocytes interacted synergically with penicillin against staphylococci at physiological $p \mathrm{H} \mathrm{(7 \cdot 2)}$ but failed to show synergy at an intraphagolysosomal $p \mathrm{H}$ of 5.0 unless the bacteria were first sublethally treated with penicillin. Experiments in which the $p \mathrm{H}$ value of culture media was changed either from $7 \cdot 2$ to $5 \cdot 0$ or from $5 \cdot 0$ to 7.2 indicated that the partial nature of the protective effect of the intraphagolysosomal environment could be attributed to the growthlimiting effects of the low phagolysosomal $p \mathrm{H}$, which prevents full expression of the synergic potential of granule contents and penicillin. The concentration-dependent nature of the protection and its incompleteness are explained by supposing that a proportion of the staphylococci not ingested during the 30 -min phagocytosis period are modified by penicillin in a way that opsonises them and potentiates the intrinsic bactericidal mechanisms of the PMN leukocytes when the bacteria are subsequently ingested.
\end{abstract}

\section{INTRODUCTION}

Studies on the accumulation of bactericidal concentrations of several antibiotics in mononuclear phagocytes and the influence of these agents on the survival of

Received 4 Dec. 1981; revised version accepted 8 Feb. 1982

Present addresses:

* Sandoz Forschungsinstitut. Department of Bacteriology, A-1235 Vienna, Austria.

+ Department of Biology, University of the West Indies, Barbados. 
intracellular microbes have been reported by Chang (1969), Patterson and Youmans (1970), Cole and Brostoff (1975), Bonventre and Gregoriadis (1978) and Brown and Percival (1978). Surprisingly little is known about the interaction between accumulated antibiotics and the antimicrobial systems of the phagocytes. Furthermore, despite obvious structural and functional differences between mononuclear and polymorphonuclear (PMN) phagocytes, most investigators have wrongly extrapolated observations made on macrophages to PMN leukocytes. The uncritical acceptance of such extrapolations partly explains the present confusion about the ability of antibiotics to penetrate into and accumulate in polymorphs.

In this communication we present evidence that penicillin does not readily penetrate or accumulate in detectable concentrations in healthy PMN phagocytes and that any penetration inferred from observations of intracellular killing of staphylococci can be attributed to extracellular modification of the bacteria before ingestion.

\section{MATERIALS AND METHODS}

Preparation of PMN leukocytes. Venous blood from adult New Zealand white rabbits weighing $c .3 .5 \mathrm{~kg}$ was drawn into siliconised screw-capped bottles containing preservative-free heparin to give a final concentration of $10 \mathrm{units} / \mathrm{ml}$ of blood. An almost pure population of PMN leukocytes was isolated from the blood by the method of Boyum (1968); the erythrocytes and polymorphs were passed through Ficoll-hypague (Pharmacia Ltd, Prince Regent Road, Hounslow, Middlesex TW3 INE.) and the erythrocytes were subsequently removed by lysis in Tris- $\mathrm{NH}_{4} \mathrm{Cl}$.

Preparation of mouse peritoneal macrophages. These were used as a known positive control in the experiments on the uptake of ${ }^{14} \mathrm{C}$-penicillin (see later). Peritoneal macrophages were harvested from mice weighing $c .25 \mathrm{~g}$. The mice were killed by cervical dislocation and the peritoneal cells washed out immediately with Eagle's minimum essential medium (EMEM) containing heparin 10 units $/ \mathrm{ml}$. The macrophages were purified by allowing them to attach to petri-dish surfaces at $37^{\circ} \mathrm{C}$ for $2 \mathrm{~h}$. Cells were recovered after a brief treatment with $0 \cdot 25 \%$ trypsin (Difco). The cells were washed three times in Hanks's balanced salts solution (HBSS) before use in the test.

Preparation of a mixed granule extract. From a suspension of PMN leukocytes containing $2.5 \times 10^{8}$ cells $/ \mathrm{ml}, 4 \mathrm{ml}$ were sonicated until $70-80 \%$ of the cells appeared to have been lysed when the suspension was viewed by phase-contrast microscopy. The lysate was then freed from unbroken cells, nuclei and any other large cellular debris by centrifugation at $126 \mathrm{~g}$ for $10 \mathrm{~min}$. The postnuclear supernate was centrifuged at $20000 \mathrm{~g}$ for $30 \mathrm{~min}$ at $4^{\circ} \mathrm{C}$ to sediment the granules. To extract the granule contents the pellet was resuspended in $1.0 \mathrm{ml}$ of $0.2 \mathrm{M}$ sodium acetate buffer at $p \mathrm{H} 4.0$ which also contained $0.01 \mathrm{M} \mathrm{CaCl}_{2}$. The extraction was continued until no trace of acid phosphatase or lysozyme was detectable. Total protein in the extract was determined by the method of Lowry et al. (1951) with bovine serum albumin (Sigma Ltd, Fancy Road, Poole, Dorset BH17 7NH) as a standard. Lysozyme was determined spectrophotometrically by extinction measurements with suspensions of Micrococcus lysodeikticus as described by Shugar (1952). Acid phosphatase was estimated by a modification of the method of O'Sullivan and Mathison (1971) for alkaline phosphatase by substituting an acid buffer $(0 \cdot 1 \mathrm{M}$ citrate buffer at $p \mathrm{H} 5.0)$.

Staphylococcus aureus suspension. S. aureus strain C18 from our stock-culture collection was stored in lyophilised form; subcultures were maintained on nutrient-agar slopes. Three colonies were taken from plate cultures and suspended in $20 \mathrm{ml}$ of Tryptic Soy Broth (TSB, Difco) in a $250-\mathrm{ml}$ conical flask. The culture was incubated at $37^{\circ} \mathrm{C}$ overnight on a rotary shaker at $200 \mathrm{rpm}$ and the suspension washed three times in HBSS. The final suspension was adjusted to $1 \times 10^{7} \mathrm{cfu} / \mathrm{ml}$ in HBSS enriched with $10 \%$ rabbit serum. At this bacterial concentration, the test culture was susceptible to penicillin at a concentration of $0.06 \mu \mathrm{g} / \mathrm{ml}$ in TSB.

Measurement of phagocytosis of staphylococci. The extent of ingestion was determined by the uridine-incorporation inhibition method (Lam and Mathison, 1979) and by counting the 
staphylococci associated with PMN leukocytes after removal of extracellular bacteria by incubation for a further $20 \mathrm{~min}$ at $37^{\circ} \mathrm{C}$ in the presence of lysostaphin $20 \mu \mathrm{g} / \mathrm{ml}$ (Easmon, Lanyon and Cole, 1978). This enzyme lyses the staphylococci rapidly without being cytotoxic to the PMN leukocytes and is not taken up by them (Tan, Watanakunakorn and Phair, 1971).

Assay of the bactericidal function of PMN leukocytes in the presence and absence of penicillin. Unless stated otherwise, the phagocytosis mixture had the following composition: $2.5 \times 10^{6}$ PMN leukocytes, $2.5 \times 10^{6} \mathrm{cfu}$ staphylococci, $0.1 \mathrm{ml}$ of serum and $0.9 \mathrm{ml}$ of HBSS contained in a polypropylene centrifuge tube. Each tube containing this mixture was incubated at $37^{\circ} \mathrm{C}$ with an end-over-end rotation at approximately $2 \mathrm{rpm}$ to promote contact between bacteria and phagocytes. After $30 \mathrm{~min}$, lysostaphin was added to give $20 \mu \mathrm{g} / \mathrm{ml}$ and the tubes were further incubated at $37^{\circ} \mathrm{C}$ for $20 \mathrm{~min}$ to lyse extracellular staphylococci. The PMN leukocytes containing ingested staphylococci were then washed twice in HBSS to remove the lysostaphin and resuspended in $1 \mathrm{ml}$ of EMEM enriched with $10 \%$ fetal-calf serum with or without appropriate concentrations of penicillin. At timed intervals, samples were removed, washed three times in HBSS containing penicillinase (Wellcome) 10 units $/ \mathrm{ml}$ and the PMN leukocytes were finally lysed in sterile $0.05 \%$ triton X-100 to release the surviving staphylococci. Six $20-\mu \mathrm{l}$ volumes of decimal dilutions of this lysate were plated out onto dried nutrient-agar plates, and colony counts after overnight incubation at $37^{\circ} \mathrm{C}$ gave an assessment of intraleukocytic killing.

Measurement of the interaction between mixed granule extract, penicillin and $S$. aureus. Mid-exponential-phase bacterial cultures containing about $1 \times 10^{7} \mathrm{cfu} / \mathrm{ml}$ were incubated for $2 \mathrm{~h}$ with either graded concentrations of granule contents and constant antibiotic concentration or vice versa. The bacteria, antibiotic and extract were contained in TSB adjusted to either $p \mathrm{H} 5 \cdot 0$ or $p \mathrm{H} 7 \cdot 2$. After incubation, six 20- $\mu$ l volumes of the mixture and decimal dilutions in TSB were plated out on dried nutrient-agar plates, incubated overnight at $37^{\circ} \mathrm{C}$ and the colonies were counted. In studies with similar mixtures, the kinetics of killing of staphylococci were also investigated. In these experiments timed samples were removed from reaction mixtures maintained at $37^{\circ} \mathrm{C}$ for up to $5 \mathrm{~h}$.

Accumulation of penicillin in PMN and mononuclear (MN) leukocytes. The uptake of penicillin was measured in studies with potassium 6-phenyl-1-14 $\mathrm{C}$-acetamido penicillinate (specific activity $51 \mathrm{mCi} / \mathrm{mmol}$ ) which was received as a powder from the Radiochemical Centre, Amersham, Bucks HP7 9LL. Fresh solutions of the radioactive drug were prepared in sterile distilled water and stored at $-190^{\circ} \mathrm{C}$. All solutions were used within 2 weeks of preparation. Purified PMN or MN leukocytes were suspended in EMEM containing $10 \%$ fetal-calf serum in which various concentrations of unlabelled penicillin were dissolved together with $0.01 \mu \mathrm{Ci} / \mathrm{ml}$ of ${ }^{14} \mathrm{C}$-penicillin. At timed intervals, $1.0 \mathrm{ml}$ portions were removed, diluted in cold HBSS containing an appropriate unlabelled penicillin and filtered within $5 \mathrm{~min}$ through $0.4-\mu \mathrm{m}$ Nuclepore polycarbonate filters. The cells on the filters were washed three times in more unlabelled penicillin solution. The filters were dried at $37^{\circ}$ for $2 \mathrm{~h}$ and counted in $1 \%(\mathrm{w} / \mathrm{v})$ butyl PBD (2-(4'-Tert-butylphenyl)-5-(4'-biphenyl)-1,3,4-oxadiazole) in toluene as scintillation fluid. The counting efficiency was $92.6 \%$. Similar penicillin-uptake studies were also performed on PMN leukocytes that had ingested heat-killed staphylococci.

\section{RESULTS}

\section{Influence of penicillin on ingestion and killing of staphylococciby rabbit PMN leukocytes}

PMN leukocytes pretreated with penicillin in concentrations up to $100 \mu \mathrm{g} / \mathrm{ml}$ for $2 \mathrm{~h}$ do not differ from untreated phagocytes in their ability to ingest and kill staphylococci. However, pretreatment of staphylococci during log-phase growth with penicillin $0.015 \mu \mathrm{g} / \mathrm{ml}$ (a $1 / 4 \mathrm{MIC}$ ) for up to $1.5 \mathrm{~h}$ rendered the bacteria significantly more susceptible to ingestion and killing by the polymorphs (table I). The number of bacteria killed by the leukocytes was much greater than could be accounted for by the increased number of intracellular bacteria. For example, pretreatment of staphylococci with penicillin for $90 \mathrm{~min}$ doubled the number of 
TABLE I

The influence of prior exposure of staphylococci to penicillin on their ingestion and killing by rabbit $P M N$ leukocytes

\begin{tabular}{l|cc}
\hline $\begin{array}{c}\text { Staphylococci grown at } 37^{\circ} \mathrm{C} \\
\text { in }\end{array}$ & Phagocytic index* & Killing index* \\
\hline $\begin{array}{c}\text { TSB for 90 min } \dagger \\
\text { TSB containing } \\
\text { penicillin for } 30 \mathrm{~min}\end{array}$ & $48 \cdot 1 \pm 3 \cdot 7$ & $21 \cdot 2 \pm 4 \cdot 3$ \\
$\begin{array}{c}\text { TSB containing } \\
\text { penicillin for } 60 \mathrm{~min}\end{array}$ & $77 \cdot 8 \pm 5 \cdot 2$ & $14 \cdot 7 \pm 6 \cdot 2$ \\
$\begin{array}{c}\text { TSB containing } \\
\text { penicillin for } 90 \mathrm{~min}\end{array}$ & $86 \cdot 3 \pm 4 \cdot 1$ & $6 \cdot 1 \pm 1 \cdot 8$ \\
\hline
\end{tabular}

* After treatment of staphylococci with penicillin $0 \cdot 015 \mu \mathrm{g} / \mathrm{ml}$ for 30,60 and $90 \mathrm{~min}$ at $37^{\circ} \mathrm{C}$, the bacteria were exposed to $\mathrm{PMN}$ leukocytes plus $10 \%$ normal rabbit serum. Ingestion and killing were measured at 30 and 120 min respectively. Results are expressed as percentages of mean value \pm SD of the zero-time sample. + See Methods.

stylococci ingested but they were approximately 20 times more susceptible to killing by the phagocytes during a $2-\mathrm{h}$ incubation period. Penicillin thus appeared to exert a "double opsonising" effect. Electronmicrographs (results not shown) of these penicillin-treated staphylococci showed multiple thick cross walls with thinner peripheral walls. We assume that these defective walls may be related to the observed penicillin enhancement of ingestion and subsequent intracellular killing by PMN leukocytes.

\section{Influence of extracellular penicillin on the killing of ingested bacteria by PMN leukocytes}

Studies to determine whether penicillin can accumulate in PMN leukocytes and kill bacteria within the phagolysosomes have not, hitherto, included control experiments showing intracellular bacterial proliferation in the face of a high extracellular

TABLE II

Protection of intracellular staphylococci from lethal extracellular penicillin during $a$ 4-h incubation period

\begin{tabular}{c|cc}
\hline \multirow{2}{*}{$\begin{array}{c}\text { Extracellular concentration } \\
\text { of penicillin } \\
(\mu \mathrm{g} / \mathrm{ml})\end{array}$} & \begin{tabular}{c} 
Number of survivors $( \pm S D)$ \\
\cline { 2 - 3 } $\begin{array}{c}\text { Intraleukocytic staphylococci } \\
\left(10^{4}\right)\end{array}$
\end{tabular} & Extracellular staphylococci \\
\hline 0 & $4 \cdot 34 \pm 1 \cdot 2$ & \\
$0 \cdot 5$ & $4 \cdot 16 \pm 3 \cdot 5$ & $2 \cdot 07 \pm 22 \cdot 0 \times 10^{6}$ \\
$1 \cdot 0$ & $3 \cdot 0 \pm 8 \cdot 4$ & $6 \cdot 88 \pm 0 \cdot 24 \times 10^{2}$ \\
$5 \cdot 0$ & $3 \cdot 09 \pm 9 \cdot 2$ & $3 \cdot 01 \pm 0 \cdot 15 \times 10^{2}$ \\
$10 \cdot 0$ & $2 \cdot 91 \pm 10 \cdot 7$ & $\ldots$ \\
$50 \cdot 0$ & $3 \cdot 38 \pm 5 \cdot 9$ & $\ldots$ \\
$100 \cdot 0$ & $2 \cdot 96 \pm 4 \cdot 3$ & $\cdots$ \\
$200 \cdot 0$ & $2 \cdot 96 \pm 7 \cdot 1$ & \\
\hline
\end{tabular}




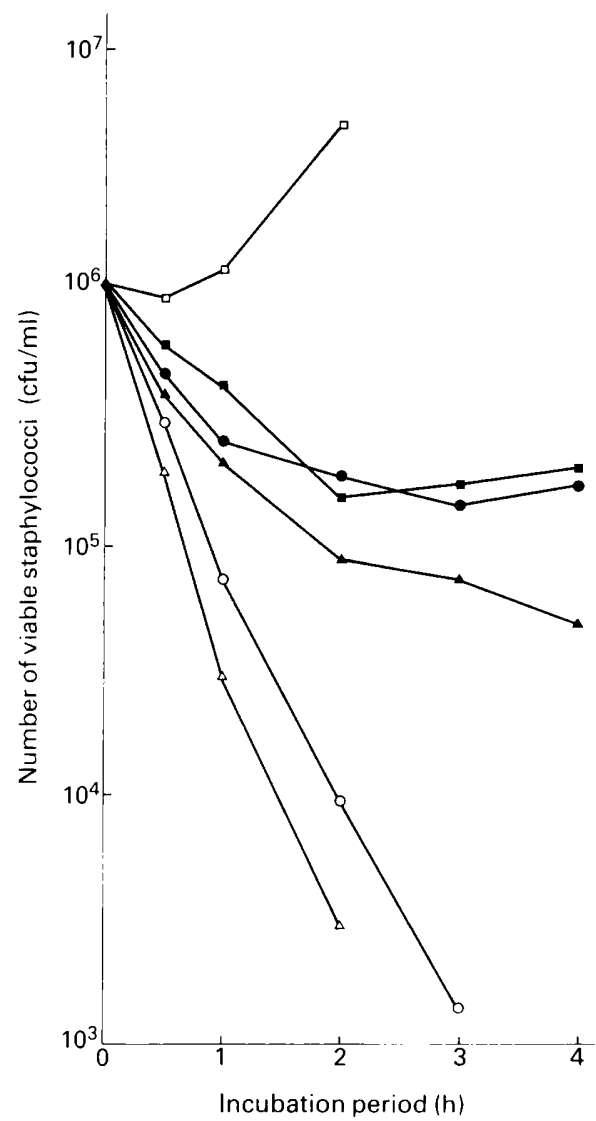

FIG. 1.-The influence of extracellular penicillin on the survival of PMN-associated staphylococci. After a 30 -min ingestion period, the uningested bacteria were removed by differential centrifugation. PMN leukocytes were then resuspended in EMEM enriched with $10 \%$ fetal calf serum ( $\boldsymbol{\square}$ ) or in medium containing penicillin (๑) $1 \mu \mathrm{g} / \mathrm{ml}$ or $(\Delta) 5 \mu \mathrm{g} / \mathrm{ml}$. At 30-min intervals, the viable bacteria were counted after residual penicillin was removed by washing. Survival plots are drawn for staphylococci in medium ( $\square$ ) and in medium containing (penicillin $1 \mu \mathrm{g} / \mathrm{ml}(0)$ and $5 \mu \mathrm{g} / \mathrm{ml}(\Delta)$. Each point is an average of three experiments.

concentration of penicillin (see Cole and Brostoff, 1975). We examined the influence of cidal concentrations of penicillin on the survival of staphylococci within rabbit leukocytes. As shown in fig. 1, intracellular staphylococci were completely protected against penicillin $1 \mu \mathrm{g} / \mathrm{ml}$ added at time 0 immediately after washing off most of the non-ingested bacteria but were only partially protected against $5 \cdot 0 \mu \mathrm{g} / \mathrm{ml}$. To investigate this apparent intracellular penicillin effect, we set up experiments in which lysostaphin was used to lyse extracellular bacteria (see Methods) before the addition of penicillin. The surviving intracellular staphylococci were then estimated after incubation for $4 \mathrm{~h}$ at $37^{\circ} \mathrm{C}$. As shown in table II, after staphylococci have taken up residence within the leukocytes they were indeed effectively protected from the lethal extracellular concentrations of penicillin.

\section{Effect of simulated phagolysosomal $p H$ on the bactericidal action of penicillin}

The intraphagolysosomal $p \mathrm{H}$ is probably about $p \mathrm{H} 5.0$ or lower (Jensen and 


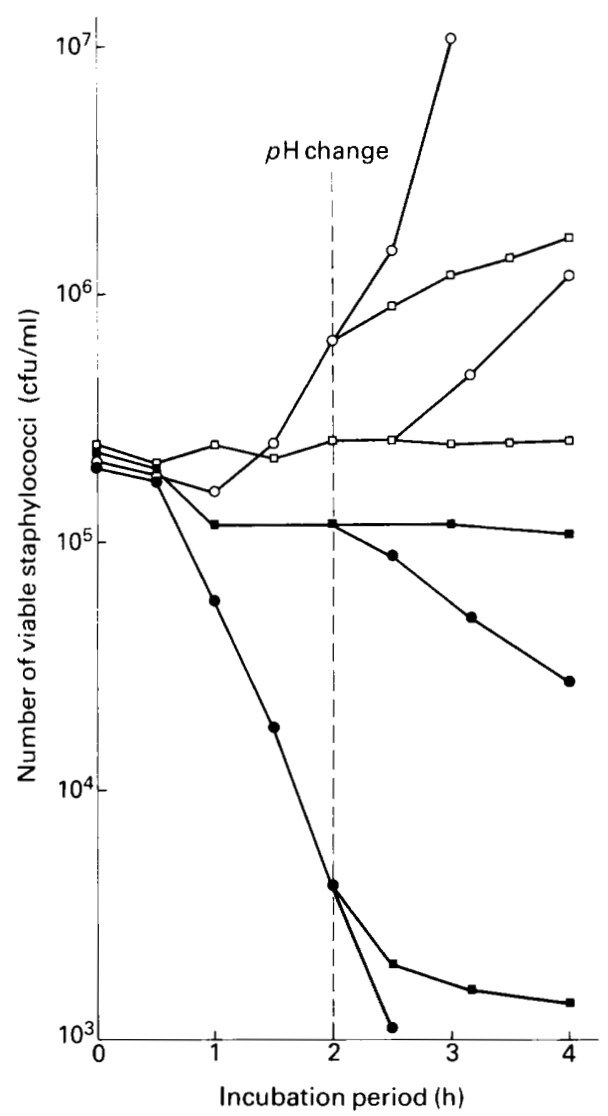

FIG. 2.-The effect of $p \mathrm{H}$ on the susceptibility of Staphylococcus aureus to penicillin. Staphylococci $\left(2 \times 10^{5}\right)$ were suspended in tryptic soy broth at $7 \cdot 2(\mathrm{O})$ or $p \mathrm{H} 5.0(\square)$ and in broth containing penicillin $1 \mu \mathrm{g} / \mathrm{ml}$ at $\mathrm{pH} 7 \cdot 2(\bullet)$ or $p \mathrm{H} 5.0(\mathbf{D})$. After incubation for $2 \mathrm{~h}$ at $37^{\circ} \mathrm{C}$ on a shaker at $200 \mathrm{rpm}$, the suspensions were washed in warm medium; the $p \mathrm{H}-5.0$ media were replaced with appropriate medium at $p \mathrm{H} 7 \cdot 2$, and vice versa. Samples were taken for viability counts at time intervals as shown (average of three experiments).

Bainton, 1973; Lam, 1980). Such a low $p H$ can of course directly affect the activity of some antibiotics, e.g., aminoglycosides, or indirectly by limiting the growth of acid-tolerant organisms and thereby rendering them less susceptible to antibiotic action. To investigate the effect of an environment at $p \mathrm{H} 5.0$ on the action of penicillin on $S$. aureus, TSB was prepared with and without penicillin $(1 \mu \mathrm{g} / \mathrm{ml})$ at $p \mathrm{H} 7 \cdot 2$ and $p \mathrm{H}$ 5.0. The media were seeded with $c .10^{5}$ staphylococci $/ \mathrm{ml}$ and incubated for $2 \mathrm{~h}$; thereafter the $p \mathrm{H} 5 \cdot 0$ cultures were adjusted to $p \mathrm{H} 7 \cdot 2$ and the $p \mathrm{H} 7 \cdot 2$ cultures adjusted to $5 \cdot 0$. Incubation was then continued for a further $2 \mathrm{~h}$. The results of this experiment (fig. 2) show that at $p \mathrm{H} 7.2$ the staphylococci were fully susceptible but at $p \mathrm{H} 5.0$ they were rather resistant to penicillin. After the $p \mathrm{H}$ changes described above, the susceptible culture rapidly became insusceptible and vice versa. The behaviour of the control cultures without penicillin suggests that this effect was due to the slowing down of bacterial growth in the case of the $p \mathrm{H}$ shift down and the commencement of growth in the case of the $p \mathrm{H}$ shift up. These results suggest that if penicillin penetrated into 
TABLE III

Uptake of ${ }^{14} C$-benzyl penicillin by mouse macrophages and rabbit PMN leukocytes during a 4-h incubation period

\begin{tabular}{c|cr}
\hline $\begin{array}{c}\text { Total extracellular penicillin } \\
\text { concentration } \\
(\mu \mathrm{g} / \mathrm{ml})\end{array}$ & \multicolumn{2}{|c|}{ Amount $(\mu \mathrm{g})$ of penicillin associated with $1 \mathrm{mg}$ of cell protein of } \\
\cline { 2 - 2 } 1 & mouse peritoneal macrophages & rabbit PMN leukocytes \\
200 & $0 \cdot 3$ & $2 \cdot 45 \times 10^{-3}$ \\
$4 \cdot 2$ & $5 \cdot 6 \times 10^{-3}$ \\
$64 \cdot 1$ & $3.06 \times 10^{-1}$ \\
\hline
\end{tabular}

PMN leukocytes it would have only a small effect on intraphagolysosomally located staphylococci provided that they were otherwise undamaged. The possibility that staphylococci partially damaged by penicillin before ingestion might not behave in this way is discussed later.

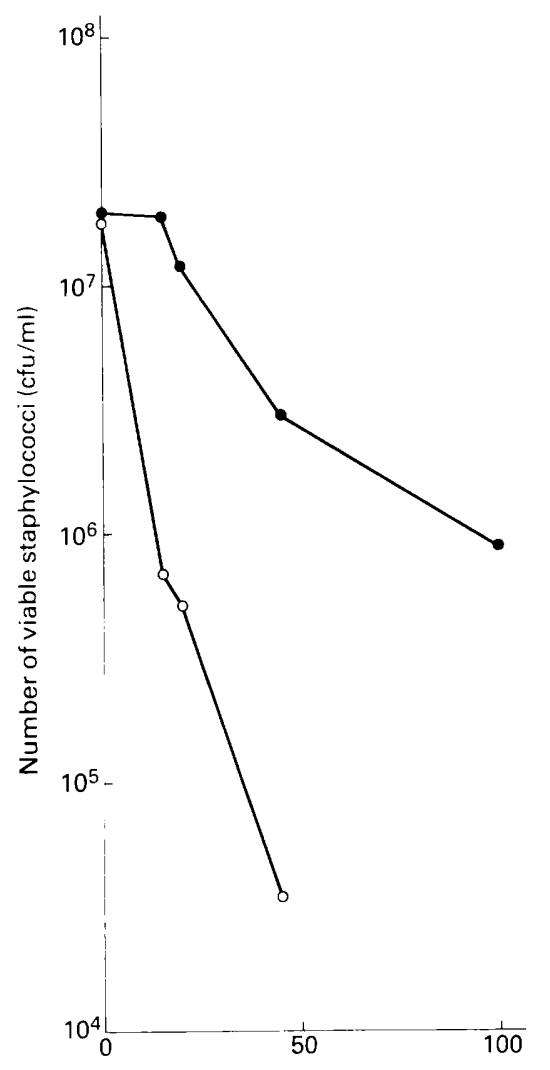

Granule extract protein concentration $(\mu \mathrm{g} / \mathrm{ml})$

FIG. 3.--Influence of penicillin on the bactericidal activity of mixed granule extracts against $S$. aureus. Washed staphylococci from an exponentially growing culture were suspended in tryptic soy broth containing various mixed granule extract contents with $(0)$ or without $(\bullet)$ penicillin $1 \mu \mathrm{g} / \mathrm{ml}$. The suspensions were then incubated at $37^{\circ} \mathrm{C}$ for $2 \mathrm{~h}$, washed, and viable bacteria counted. Each point is an average of three experiments done on different days. 


\section{Permeability of PMN leukocytes to penicillin}

We followed the method of Lowrie, Aber and Carrol (1979) who demonstrated a rapid accumulation of ${ }^{14} \mathrm{C}$-labelled benzyl penicillin into mouse peritoneal macrophages. We have confirmed that penicillin does penetrate into mouse macrophages, but we have failed to detect any penetration into rabbit PMN leukocytes. The PMN leukocytes were monitored for radioactivity at $0,2,4$ and $24 \mathrm{~h}$ but none was detectable. It is remotely possible that penicillin penetrated into the leukocytes and was subsequently leached out during the washing procedures, but this is unlikely because it did not occur with either freshly isolated or laboratory conditioned peritoneal macrophages. The results of these experiments are summarised in table III.

\section{Synergic interaction between PMN leukocyte mixed granule extract and penicillin}

When exponential-phase cultures of staphylococci were incubated in TSB containing a fixed concentration of penicillin with graded concentrations of mixed

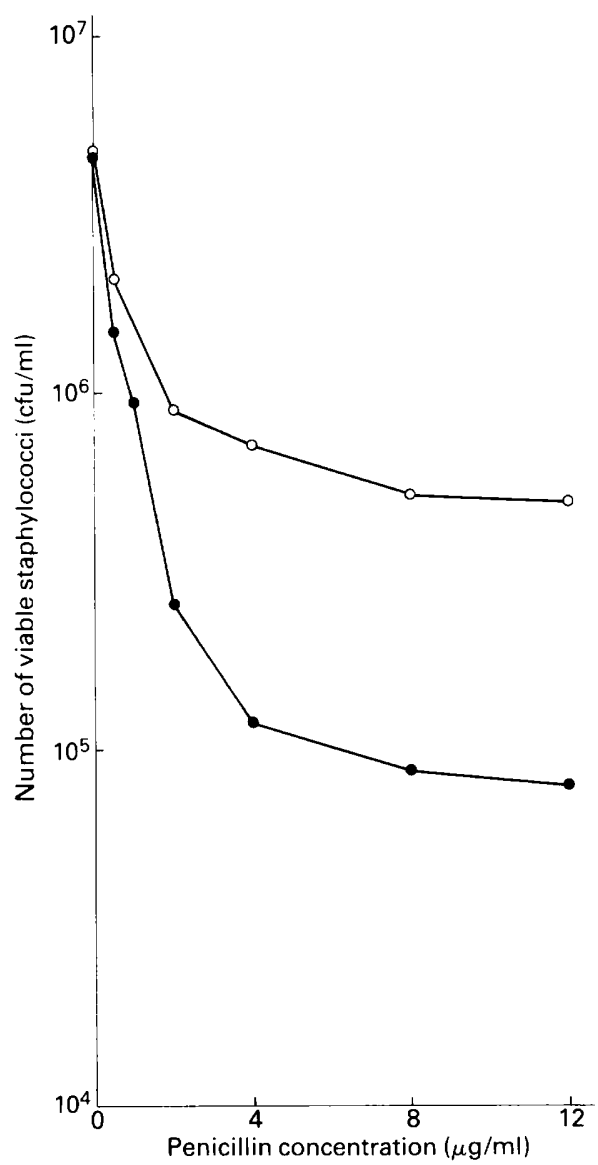

FIG. 4.--Influence of mixed granule extract on the bactericidal activity of penicillin. Washed staphylococci from an exponentially growing culture were suspended in tryptic broth containing various penicillin concentrations with $(\mathrm{O})$ or without $(\bullet)$ granule extracts (total protein $40 \mu \mathrm{g} / \mathrm{ml}$ ). After incubation for $2 \mathrm{~h}$ at $37^{\circ} \mathrm{C}$ the surviving staphylococci were counted. Each point is an average of three experiments done on different days. 


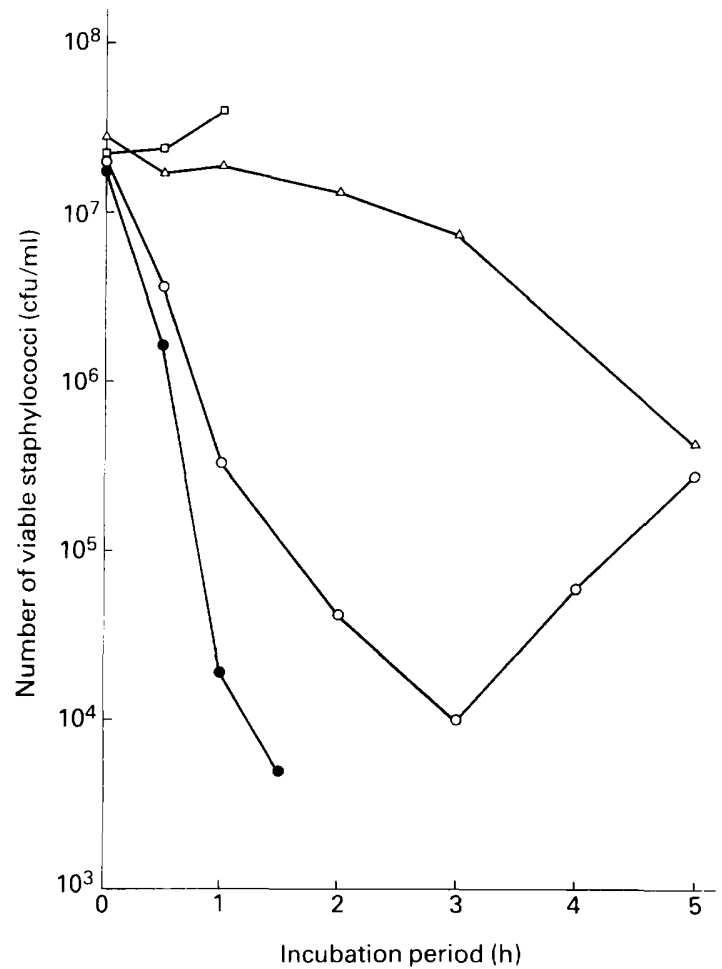

FIG. 5.-Time course of the synergistic interaction between penicillin and mixed granule extracts in killing staphylococci. The bacteria were incubated in TSB ( $\square$ ) or TSB containing either penicillin $1.2 \mu \mathrm{g} / \mathrm{ml}$ (O), granule extract $40 \mu \mathrm{g} / \mathrm{ml}(\Delta)$ or penicillin and granule extract $(\bullet)$. At 30-min intervals, the viable bacteria were estimated, after washing off the residual extract and penicillin. Each point is the mean of three experiments.

granule extract (fig. 3) or vice versa (fig. 4), the number of bacteria killed during a 2-h incubation period at $37^{\circ} \mathrm{C}$ was much greater than could be attributed to the additive effects of the two acting individually. This synergic interaction was also demonstrated by time-course experiments in which fixed concentrations of both penicillin and mixed granule extract were allowed to act on the staphylococci over a 5-h period during which samples were removed for viable counting at hourly intervals (fig. 5). All of these experiments were done at $p \mathrm{H} \mathrm{7.2}$ and it must be said that we failed to demonstrate this synergic interaction at $p \mathrm{H} 5 \cdot 0$. This does not mean, however, that the results are without significance for the intracellular environment (see below).

\section{Influence of pretreatment of staphylococci with either penicillin or mixed granule extract on their survival in media containing either penicillin or granule extract}

In studies to determine whether mixed granule extract and penicillin acted in concert or sequentially, the bacteria were pretreated sublethally either with penicillin $1.2 \mu \mathrm{g} / \mathrm{ml}$ for $1 \mathrm{~h}$ at $37^{\circ} \mathrm{C}$ before addition of mixed granule extract $40 \mu \mathrm{g} / \mathrm{ml}$ or with the same concentration of granule extract for $30 \mathrm{~min}$ at $37^{\circ} \mathrm{C}$ before addition of the penicillin. Although neither penicillin nor granule extract alone exhibited bactericidal activity in these test conditions, preincubation with penicillin followed by addition of 
granule extract resulted in a significant killing (viable numbers of bacteria decreased by

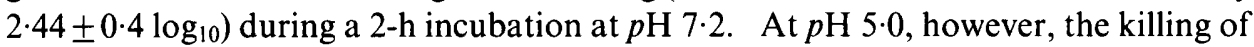
the bacteria was less but nevertheless significant (viable numbers decreased by $\left.0 \cdot 4 \pm 0 \cdot 11 \log _{10}\right)$. In contrast, preincubation with mixed granule extract followed by addition of penicillin produced no further killing at $p \mathrm{H} 5.0$ and a less dramatic killing at $p \mathrm{H} 7 \cdot 2$ (viable numbers decreased by $1 \cdot 15 \pm 0 \cdot 3 \log _{10}$ ). These results indicate that penicillin pretreatment prepares the staphylococci for killing by PMN granule enzymes, whereas granule extract treatment has no influence on the survival of these bacteria in acidic medium containing lethal concentrations of penicillin.

\section{DisCUSSION}

There seems little doubt that penicillin can penetrate into mononuclear leukocytes of various types (Cole and Brostoff, 1975; Brown and Percival, 1978; Lowrie et al., 1979; Johnson et al., 1980), but there has been some confusion as to whether it can penetrate also into PMN leukocytes. The results of the present study show that rabbit PMN leukocytes are not significantly permeable to benzyl penicillin when they are examined in conditions in which accumulation of the drug by macrophages could easily be detected. The inability of a lethal concentration of penicillin in the extracellular fluid to kill staphylococci that have taken up residence within the phagocytes (Solberg, 1972; Mandell, 1973; Solberg and Hellum, 1978; Easmon, 1979; and table II) supports the above findings.

However, it is not easy to demonstrate this protection phenomenon consistently; much depends, amongst other things, on the experimental techniques and upon the type of ingested micro-organism (see Veale et al., 1975, 1976 and 1979). Whereas protection of an intracellular staphylococcal population obtained by simple washing procedures of extracellular bacteria was complete at a penicillin concentration of 1 $\mu \mathrm{g} / \mathrm{ml}$, the protection was only partial at $5 \mu \mathrm{g} / \mathrm{ml}$. In experiments in which extracellular non-ingested bacteria were lysed with lysostaphin, marked protection was observed at all concentrations tested. The discrepancy between the two types of experiment is not directly attributable to the permeation of penicillin into the phagocytes (Mandell, 1973), but is probably due to the action of the drug on phagocyte-attached bacteria that could not be removed by simple washing procedures. The experiments with penicillin-treated staphylococci offer an explanation for the apparent intracellular effect observed. Pretreatment of staphylococci during logphase growth rendered them more susceptible to ingestion and subsequent intracellular killing by the phagocytes. Similar penicillin-mediated hypersensitivity of bacteria to killing by leukocytes has been reported (Alexander and Good, 1968; Adam et al., 1972; Horne and Tomasz, 1981; and Root et al., 1981). However, the possible biochemical basis for this penicillin-induced susceptibility is unknown at present. Recent reports suggest that the drug enhances loss of antiphagocytic capsular material from the bacteria (Horne and Tomasz, 1981) leading to the destruction of the natural permeability of the bacterial cell envelope. Such antibiotic-damaged bacteria can therefore expose more binding sites for complement factors (Gemmel et al., 1981) and once ingested allow better access of PMN lysosomal enzymes.

The mechanisms by which PMN leukocytes protect ingested bacteria from lethal concentrations of extracellular penicillin is also not yet clear. The results of the 
present study with mixed granule extracts offer some explanations for the protection

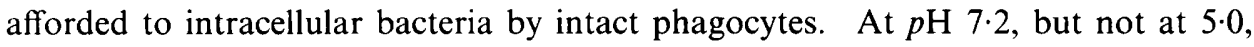
mixed granule extract acted synergically with penicillin to kill staphylococci. It is thus conceivable that the low intraphagolysosomal $p \mathrm{H}$ achieved during the respiratory burst (Mandell, 1970; Jensen and Bainton, 1973; Lam, 1980) reduces the staphylococcal growth rate. These non-dividing bacteria will thus become more resistant to penicillin. Protection afforded by the intraphagolysosomal environment can thus be seen to be made up of a permeability barrier against intracellular accumulation of penicillin plus a limitation of the synergic interaction between granule contents and penicillin by the low $p \mathrm{H}$. Further support for this hypothesis comes from our observed impairment of staphylococcal sensitivity to penicillin at $p \mathrm{H} 5$. A transition from a bacteriostatic to a bactericidal response to penicillin was observed when the $p \mathrm{H}$ was increased from 5 to $7 \cdot 2$.

The observations with mixed granule extracts and penicillin are, to our knowledge, the first experiments of this kind to be reported for evaluation of the possible influence of antibiotics on bacterial intracellular survival. Whereas preincubation of the staphylococci during log-phase growth with penicillin rendered them easily killed by

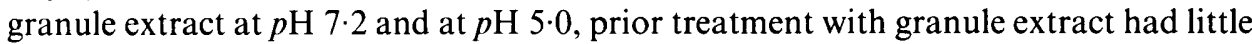
effect on the survival of the bacteria in media containing penicillin at $p \mathrm{H} 5$. It is conceivable that these events can occur in the micro-environment of the interior of the phagolysosome. Antibiotic-damaged but still viable staphylococci are rapidly killed within the phagolysosomes shortly after phagocytosis even when the intraphagolysosomal $p \mathrm{H}$ is still about 5. However, granule enzyme-damaged bacteria cannot be killed by penicillin at $p \mathrm{H} 5$ even if it were to accumulate into the leukocytes.

It should be stressed that our results should not be applied uncritically to other bacteria, other antibiotics or to other types of phagocytic cells. Easmon (1979) has shown that some antibiotics, in particular aminoglycosides and rifampicin, exert an intracellular effect in human PMN leukocytes far greater than that of penicillins and this implies some penetration. We strongly advocate that antibiotics should not be used to remove extracellular bacteria in leukocyte-function tests or other experiments involving phagocytosis unless the conditions that influence their penetration are clearly defined; in many examples in the literature it is clear that these factors have not been defined.

We wish to thank the Science Research Council for a studentship to one of us (C.L.), and Mrs C. Janata and Miss H. Wernbacher for their excellent secretarial assistance.

\section{REFERENCES}

Adam, D., Staber, F., Belohradsky, B. H. and Marget, W. 1972. Effect of dihydrostreptomycin on phagocytosis of mouse-peritoneal macrophages in vitro. Infection and Immunity, $5,537-541$.

AlEXANDER, J. W. AND GOOD, R. A. 1968. Effect of antibiotics on the bactericidal activity of human leukocytes. Journal of Laboratory and Clinical Medicine, 71, 971-983.

Bonventre, P. F. AND GRegoriadis, G. 1978. Killing of intra-phagocytic Staphylococcus aureus by dihydrostreptomycin entrapped within liposomes. Antimicrobial Agents and Chemotherapy, 13, 1049-1051.

Boyum, A. 1968. Separation of leukocytes from blood and bone marrow. Scandinavian Journal of Clinical Investigation, 21, supplement 97. 
Brown, K. N. ANd Percival, A. 1978. Penetration of antimicrobials into tissue culture cells and leukocytes. Scandinavian Journal of Infectious Diseases, supplement 14A, 251-260.

CHANG, Y. T. 1969. Suppressive activity of streptomycin on the growth of Mycobacterium lepraemurium in macrophage cultures. Applied Microbiology, 17, 750-754.

COLE, P. AND BROSTOFF, J. 1975. Intracellular killing of Listeria monocytogenes by activated macrophages (Mackaness system) is due to antibiotic. Nature, London, 256, 515-517.

EASMON, C. S. F. 1979. The effect of antibiotics on the intracellular survival of Staphylococcus aureus in vitro. British Journal of Experimental Pathology, 60, 24-28.

Easmon, C. S. F., LANYon, H. AND Cole, P. J. 1978. Use of lysostaphin to remove cell-adherent staphylococci during in vitro assays of phagocyte function. British Journal of Experimental Pathology, 59, 381-385.

Gemmel, C. G., Peterson, P. K., Schmeling, D., Kim, Y., Mathews, J., Wannamaker, L. And QuiE, P. G. 1981. Potentiation of opsonization and phagocytosis of Streptococcus pyogenes following growth in the presence of clindamycin. Journal of Clinical Investigation, 67, 1249-1256.

Horne, D. AND TOMASZ, A. 1981. Hypersusceptibility of penicillin-treated group B streptococci to bactericidal activity of human polymorphonuclear leukocytes. Antimicrobial Agents and Chemotherapy, 19, 745-753.

JENSEN, M. S. AND Bainton, D. F. 1973. Temporal changes in $\mathrm{pH}$ within the phagocytic vacuole of the polymorphonuclear neutrophilic leukocyte. Journal of Cell Biology, 56, 379-388.

Johnson, J. D., Hand, W. L., Francis, J. B., King-Thompson, N. And Corwin, R. W. 1980. Antibiotic uptake by alveolar macrophages. Journal of Laboratory and Clinical Medicine, 95, 429-439.

LAM, C. 1980. Interaction between antibiotics, polymorphonuclear leukocytes and Staphylococcus aureus, $\mathrm{PhD}$ Thesis, University of London.

Lam, C. AND Mathison, G. E. 1979. Phagocytosis measured as inhibition of uridine uptake: a method that distinguishes between surface adherence and ingestion. Journal of Medical Microbiology, 12, 459-467.

Lowrie, D. B., ABER, V. R. AND CARrol M. E. W. 1979. Division and death rates of Salmonella typhimurium inside macrophages: use of penicillin as a probe. Journal of General Microbiology, 110, 409-419.

Lowry, O. H., Rosebrough, N. J., FarR, A. L. AND Randall, R. J. 1951. Protein measurement with the Folin phenol reagent. Journal of Biological Chemistry, 193, 265-275.

MANDELL, G. L. 1970. Intraphagosomal pH of human polymorphonuclear neutrophils. Proceedings of the Society for Experimental Biology and Medicine, 134, 447-449.

MANDELL, G. L. 1973. Interaction of intraleukocytic bacteria and antibiotics. Journal of Clinical Investigation, 52, 1673-1679.

O'Sullivan, J. AND Mathison, G. E. 1971. The localization and secretion of a proteolytic enzyme complex by the dermatophytic fungus Microsporum canis. Journal of General Microbiology, 68, 319-326.

Patterson, R. J. AND Youmans, G. P. 1970. Multiplication of Mycobacterium tuberculosis within normal and immune mouse macrophages cultivated with and without streptomycin. Infection and Immunity, 1, 30-40.

Root, R. K., Isturiz, R., Molavi, A., Metcalf, J. A. and Malech, H. L. 1981. Interactions between antibiotics and human neutrophils in the killing of staphylococci. Studies with normal and cytochalasin B-treated cells. Journal of Clinical Investigation, 67, 247-259.

ShugaR, D. 1952. The measurement of lysozyme activity and ultra violet inactivation of lysozyme. Biochimica et Biophysica Acta, 8, 302-309.

SolBerg, C. O. 1972. Protection of phagocytosed bacteria against antibiotics. A new method for the evaluation of neutrophil granulocyte functions. Acta Medica Scandinavica, 191, 383-387.

Solberg, C. O. ANd Hellum, K. B. 1978. Protection of phagocytosed bacteria against anti-microbial agents. Scandinavian Journal of Infectious Diseases, supplement 14, 246-250.

Tan, J. S., Watanakunakorn, C. And Phair, J. P. 1971. A modified assay of neutrophil 
function: use of lysostaphin to differentiate defective phagocytosis from impaired intracellular killing. Journal of Laboratory and Clinical Medicine, 78, 316-322.

Veale, D. R., Finch, H., Smith, H. ANd Witt, K. 1976. Penetration of penicillin into human phagocytes containing Neisseria gonorrhoeae: intracellular survival and growth at optimum concentration of antibiotic. Journal of General Microbiology, 95, 353-363.

Veale, D. R., Goldner, M., Penn, C. W., Ward, J. and Smith, H. 1979. The intracellular survival and growth of gonococci in human phagocytes. Journal of General Microbiology, 113, 383-393.

Veale, D. R., Smith, H. ANd Witt, K. 1975. Penetration of penicillin into human phagocytes containing gonococci. Lancet, 1, 306-308. 